\title{
Territorialization and Logistics of Knowledge and Learning: the Case of Mineral Resource Surveys in France in the Eighteenth Century.
}

\author{
Isabelle Laboulais (University of Strasbourg - EA 3400 / ARCHE)
}

Following the path opened by Michel Foucault's classes on gouvernamentalité, the history of State knowledge has revealed the "acts by which the government of subjects and populations are operated." ${ }^{1}$ This perspective aimed to apprehend the manner in which central or local administrative offices collected, organized, stored and disseminated information on people, goods and the territory. ${ }^{2}$ In the 1980s, Jean-Claude Perrot followed by Marie-Noëlle Bourguet, made statistical surveys of 18th century the object of their own research.3 More than results, it was the method and the structure of the surveys which were the focus of their studies which sought to analyze the mechanisms of knowledge. They established the principle of an omnipresent will to know, which resulted in the collection of quantitative and qualitative elements. They also identified the existence in the eighteenth century of composite practices that did not distinguish between uses that were specific to administration or to scholarly circles. On the contrary, they provided numerous examples to show that in the eighteenth century, administrators and scholars employed similar collection techniques, that they had designed questionnaires shaped by the same logic, and that over the decades, their spectra of observations widened. These works, as well as those they inspired, 4 have highlighted the existence, from the 1760s, of what Bernard Lepetit called a "movement toward the territorialization of knowledge".5

The pragmatic turn taken by the history of knowledge now offers the possibility of reexamining this issue from new perspectives. The material approach to administrative work focuses on how central or local government offices collect, organize, store and disseminate information about people, goods, and territory. What we are dealing with are

\footnotetext{
${ }^{1}$ Michel Foucault, Naissance de la biopolitique : cours au Collège de France, 1978-1979, éd. Par M. Senellart sous la dir. de F. Ewald et A. Fontana, Paris, Gallimard/Le Seuil, 2004. Sur les usages par les historiens de la notion de gouvernementalité, on verra le dossier des Annales, Histoire, Sciences sociales, 2007, $n^{\circ} 5$. Dans la présentation de ce dossier que donne Paolo Napoli, il relève que la gouvernementalité est un « instrument heuristique que Foucault construit à partir des objets historiques examinés », il ne s'agit pas d'un « fait identifiable comme tel mais une manière de donner du sens à des faits hétérogènes », p. 1124.

2 BUTON (François), "L'observation historique du travail administratif ", Genèses, 2008, n 72, p. 2-3.

3 Jean-Claude Perrot, L'âge d'or de la statistique régionale française (an IV - 1804), Paris, Société des études robespierristes, 1977. Jean-Claude Perrot also returned to this question in: De la richesse territoriale du Royaume de France de Lavoisier, Paris, CTHS, 1988 and Une histoire intellectuelle de l'économie politique (XVIle-XVIIle siècle), Paris, EHESS, 1992. Marie-Noëlle Bourguet, Déchiffrer la France. La statistique départementale à l'époque napoléonienne, Paris, Éditions des archives contemporaines, 2001, $2^{\text {nd }}$ ed. (1988, 1st edition).

${ }^{4}$ Philippe Minard, "Volonté de savoir et emprise d'État. Aux origines de la statistique industrielle dans la France d'Ancien Régime", Actes de la recherche en sciences sociales, No. 133 (1), 2000, p. 62-71.

${ }^{5}$ Bernard Lepetit, "Missions scientifiques et expéditions militaires : remarques sur leurs modalités d'articulation", in Marie-Noëlle Bourguet, Bernard Lepetit, Daniel Nordman and Maroula Sinarellis, L'invention scientifique de la Méditerranée, Paris, EHESS, 1998, p. 98.
} 
logistics of knowledge, that is to say, "a set of tools and practices aimed at organizing the collection, archiving and extraction of types of information in order to mobilize them" (Denis/Lacour).6 The study of the material and formal means used to collect, select, conserve, and disseminate data leads the historian to take documents of a varied nature into account: correspondence, tables, reports... produced on a daily basis (often anonymously) in adminstrative offices. All these documents contain data whose aggregation produces significant information that contributes to the production of administrative knowledge.

My starting point for this study will be the late eighteenth- and early nineteenthcentury investigations carried out in France, when mines entered the scope of State action. I would like to highlight how the collection of knowledge vital to the boom in mining operations significantly involved territorial agents who developed new methods for the organization of data. I will conclude by returning to the question of how scholarly and bureaucratic knowledge interacted in the particular context of the administration and operation of mines in France. This observation will lead me ultimately to come back to the issue of how scientific and administrative knowledge interacted in the specific context of mines.

\section{The organization of mineral resource surveys}

The first report devoted to mineral resources in France, the Enquête du Régent (1716-1718) served a double purpose: it offered both an account of the kingdom's mineral and natural wealth and an evaluation of the benefits that the exploitation of these resources could offer to the advancement of the trade and industry. 7 The Royal Academy of Sciences oversaw the development of the investigation's general strategy and articulated the instructions that the Regent addressed to the agents, who sometimes would travel in person to collect the data. Most of them, however, generally used informants who either were subdelegates (judges, ingénieurs du roi, members of learned societies like the provincial academies) or were private individuals (miners, priests, soldiers). Though the investigation generated some interest and made it possible to collect many samples of descriptive and material data, it did not lead to the development of any tools likely to resolve the perplexing difficulties of accumulating information.

As new prospection and extraction techniques emerged and consolidated the dominant positions of Sweden, England and the Germanic regions, the French administration increasingly concerned itself with the training of operators, technicians and miners. Most of the investigations carried out by the administrative staff were still based on the inventory model, aimed at collecting data based on observation. In the course of the

\footnotetext{
${ }^{6}$ Vincent Denis, Pierre-Yves Lacour, "La logistique des savoirs. Surabondance de l'information et technologies de papier au XVIIle siècle", Genèses, 2016/1, No. 102, p. 105.

${ }^{7}$ Christiane Demeulenaere-Douyère, David J. Sturdy, L'enquête du Régent, 1716-1718. Sciences, techniques et politique dans la France préindustrielle, Turnhout, Brepols, 2008.
} 
eighteenth century, more specific investigations organized by the Contrôle général were dedicated to mines $(1741,1742,1764$ and 1783) or metallurgy $(1772,1774$, and 1788).8 Although the resulting reports combined descriptive elements and quantitative data, they testify already in the 1740 s to the formalization of a practical science of industrial enumeration, based on a model akin to that developed by mathematicians for demographic statistics.

Despite the efforts of various institutions in the eighteenth century to encourage the use of a skilled eye during professional travels, central administrations did not standardize their collection procedures, nor did they employ agents specifically responsible for investigative work. The need for men experienced in mine operations and able to identify the resources to be exploited led Orry to use funds from the Contrôle général to send young men to territories known for their mining techniques. In 1742, Saxony and Hanover were the destination for Bleumenstein, son of a powerful mining magnate, and Saur, son of a mining operator in Alsace.9 This practice continued until the end of the 1750s. Between 1759, the date of Bertin's entry into the Contrôle général, and 1780, when he left his state secretariat, this practice of travel continued. However, it no longer contributed to the training of future miners but to that of administrators or engineers working in monarchical institutions. It is in this context that Gabriel Jars travelled to England, Hanover, Sweden, and the Harz. On behalf of the Contrôle général, he also visited different French provinces in order to observe and describe the technical processes and legal organization of their mining operations.10 In 1772, Bertin formalized this organization by creating a mining office in which two men, Jourdan and Monnet, were first employed "to visit the mines". On June 17, 1776, they each received the title of inspecteur general des mines charged with "visiting the said mines, to draw up reports of their situation, direction, inclination, nature, quality and richness of the way in which they are operated".11 They concentrated their activity on the monarchy's territory: the inspections they carried out were supposed to contribute to the knowledge of mineral resources and the privileged scale of their interventions was that of exploitation.

The inspectors received specific instructions for their investigations: when in the field, they were to situate the mine in its natural and economic environment. Their description had to address the mine's physical characteristics (direction of the veins, nature of the gangues), as well as the legal framework of its exploitation; additional attention was brought to the technical equipment (galleries, wells, water pumps), the natural resources

\footnotetext{
${ }^{8}$ Denis Woronoff, L'industrie sidérurgique en France pendant la Révolution et l'Empire, Paris, EHESS, 1984, p. 54.

${ }^{9}$ Arthur Birembaut, "L'enseignement de la minéralogie et des techniques minières", in Roger Hahn, Rene Taton, Ecoles techniques et militaires, Paris, Hermann, Histoire de la pensée, 1986, p. 365-418.

10 Isabelle Laboulais, "Les Voyages métallurgiques de Gabriel Jars (1774-1781), un imprimé au service de l'art de l'exploitation des mines", in Pierre-Yves Beaurepaire and Pierrick Pourchasse (eds.), Les circulations internationales en Europe (1680-1780), Rennes, Rennes University Press, 2010, p. 181-196.

${ }^{11}$ Bertrand Gille, "L'administration des mines en France sous l'Ancien Régime", Revue d'histoire des mines et de la métallurgie, t. I, vol. 1, 1969, p. 3-35.
} 
surrounding the mine (wood, water), and communication routes. The map was presented as an indispensable tool for the valuation of the mine. It accompanied the record of operations and the quantitative status of production which was to follow the model provided by the Contrôle général to contain "the most accurate results". To do this, inspectors had not only to be attentive to the mining output, but they also had to consider the operation of the company. Through these visits, they were expected to provide accurate information to the Contrôle général but they also acted on the local level advising both operators, who were encouraged to develop coal mining, and workers to whom they explained how to separate the minerals from the worthless materials that could complicate transportation. Inspectors provided a form of technical support for drilling, cleaning and drying so that these processes would always be conducted as economically as possible. Field work was also an opportunity to identify mine indexes and to take samples. The inspectors were instructed to be particularly attentive to certain of France's rarest holdings (vitriol, alum, saltpeter, tin mines, etc.), the development of which would be fostered by their work.

These instructions confirm that in the mid-eighteenth century, data on the economic and social arenas were expected to become instruments of the "rationalization of public decision" (Margairaz). However, by the very admission of one of the inspectors, the organization of the mining office did not make it possible to acquire better knowledge of this sector. The inspector Monnet pointed out in one of this writings that the Ancien Régime administration faced difficulty in mobilizing the data gathered during investigations or inspection tours.12 Monnet gives the impression that the data collected went unused by the administration, not because of lack of interest, but rather because of the lack of a method to process it. By creating the Maison des Mines in Paris in Year II (French Republican Calendar, 1793-94), the Committee of Public Safety tried to resolve this difficulty.

\section{Which logistics for administrative knowledge? The challenge of a building}

From the summer of 1794 when an inspection of mines was created with eight inspectors, twelve engineers and twenty students, a "Maison des Mines" was established at 293 rue de l'Université. It gathered office workers, members of the Inspection des mines, and scientists of various notoriety, some of whom found shelter there, while others, such as Haüy and Dolomieu, found a source of income. The site was also the centralized location of mining expertise since the information and objects drawn from the engineers' field work converged upon the Maison des Mines to be mobilized by the advisers and the Conférence

\footnotetext{
12 "Nous voyageâmes pourtant et les mémoires que nous leur [il s'agit des intendants de commerce] remîmes sur ce que nous avions vu eurent le sort de tous les autres qu'on avait remis précédemment à l'administration, ils furent mis dans des cartons et oubliés", Library of the Ecole des Mines de Paris, ms. 5, Monnet (AntoineGrimoald), "Essai historique sur l'administration des mines en France", 1793, f. 79-80.
} 
des mines to design the most effective operational projects possible. It was also where future engineers received the rudiments of "mining science" during public courses offered there. The Maison des Mines appears as the place where the expertise of a technical corps is built, but it also it offered spaces for the development, storage and classification of knowledge. In addition to the mining administration's archives, there were experimental laboratories, mineralogical collections, the library. Distributed between the ground floor and the first floor, the Mining Corps' archives additionally contained samples, books, handwritten manuscripts, as well as maps and tools used not only by the inspectors, engineers and mining students, but also by the heads of offices in charge of the administration of mineral resources.

The site embodied something quite new in the scholarly Paris of the late eighteenth century. Of course, during the 1780s, a Royal Mining School had been created at the Hôtel de la Monnaie, and, at the same time, a Mining Administration had taken shape in the offices of the Contrôle général, but these two entities' operations were in no way coordinated. The development of the Maison des Mines created a doubly unique situation in Revolutionary Paris: the spheres of scholarship and administration were brought together in a single building, a place where scientists and administrators used the same tools13.

During the eight months they spent in the mineralogical districts, the members of the inspection team were required to transmit their reports, journals and drawings to the agency every ten days, without the content or the uses of these documents being specified in the texts. Though the extant archives today show a great variety in the texts that contributed to the knowledge both of resources and of local operations, it is possible to identify three types: reports on mines, reports on the mineralogy of a specific region or borough, and mineralogical journals. In addition to these documents, there are of course the letters that the men in the field sent to Paris and the tables of data organized by place of production or by product. Once centralized at the Maison des Mines, the descriptive information was sorted and compiled; the processing of data collected by inspectors and mining engineers in the field led to the introduction of new tasks in the offices and the development of specific tools.

The summaries of production according to location could take various forms. The oldest genre, likely inherited from the Ancien Régime, is a repertoire that summarizes the main characteristics of each mine. This type of document presented its information in two columns: the column on the right presented exclusively descriptive data deemed useful to characterize the resources; the column on the left detailed the sources of the descriptive date, and it was used to add references to documents that supplemented or modified previously collected information. These indications show that the reports composed under the Ancien Régime were used in the same way as those written from the Year II to establish

\footnotetext{
${ }^{13}$ Isabelle Laboulais, La Maison des mines : la genèse révolutionnaire d'un corps d'ingénieurs civils (1794-1814), Presses universitaire de Rennes., 2012
} 
the directory of mines. Each departmental heading is subdivided by district or township, and the mines are presented according to the nature of their products. Each mine is usually assigned a number that may be a code to sort documents.

These fact sheets were easier to manipulate in order to mobilize accurate information. Presumably, such lists were drawn up by office employees of the agency and then the Conseil des Mines based on the correspondence and reports of engineers, as well as answers obtained from the Brumaire Year III Inquiry (October-November 1794). Each sheet is a digest of information devoted to a particular mining operation. All transcribed information is presented in a synthetic and standardized format, as most of the cards are identical in structure: the situation of the mine is specified (name of the township and the town), the number of the Cassini map on which it is represented also appears; then data specific to each operation (date of establishment, number of workers, raw materials used, fuels used and the consumption of them, products, markets). Finally, at the bottom of each card, the name of the person who transmitted the information is noted, as well as the date on which they communicated it 14 . All the details are not always complete. According to the sources of information, the elements are more or less precise. The mines recorded on some cards are marked "to visit" or "to check"; an entry for "observations" sometimes appears at the end of the form and contains assessments of operations' quality. Records of this type were also compiled to keep track of the indexes reported to the Agency and then to the Mining Council. Such documents would seem to be evidence of what Philippe Minard called "the temptation of the topographic dictionary" 15.

The standardization of these cards aimed to facilitate their subsequent processing. All the files were sorted according to the territorial organization established at the beginning of the Revolution; this system functioned as a homogeneous mesh (department, township, town) and as a grid to rank the documents. Sometimes they were classified together in a subfolder called État statistique des richesses minerals $d u$ département16. Most of these files seem to have been drawn up between Year III and Year IV, that is to say, at a time when the agency and later the Conseil des mines had a large clerical staff. These summary sheets were probably used to prepare the instructions for the mining engineers, but they also clearly served as the basis for the document entitled Mines et usines à visiter par les membres de l'inspection 17. This register listed the mining indexes or the information received on the sites for each department; compared to the departmental files, it had the advantage of centralizing in a single document the information to be verified, making it possible to prioritize the tasks to be assigned to the engineers and inspectors of the mines. As historians of science have shown, particularly by studying the methodology of Linnaeus, such sheets enable the introduction and sorting of data for

\footnotetext{
${ }^{14}$ Archives nationales (AN), F 144234

15 Philippe Minard, "Volonté de savoir et emprise d'État, art. cit., p. 68

${ }^{16}$ AN, F 14 4239, Dossier Doubs.

${ }^{17}$ AN, F 14 1315, s. d.
} 
selection and cross-referencing. They were indeed an important tool for facilitating the construction of mine knowledge 18.

The lack of a classification system for the tables used during the same period at the Maison des Mines is evident in the variability of their titles. For some departments, there are documents that list the resources identified in the constituency; they are sometimes entitled "reports on the resources of the department", sometimes "mining chart", sometimes "state of known mines". Indeed, their content and organization change from one author to another. However, it can generally be noted that these are summary documents that present quantitative data detailed in columns with the characteristics of each mine, usually listed township by township. These tables mention the location of the mines; the designation and nature of ore deposits; the name of the owner and the manager; the quantity, price and value of the extracted products; the sites of consumption; the means of transport used; the number of salaried workers. The last column is reserved for observations, and it contains elements relating to the operation and its history, such as information on past enterprises. Some tables collect data on mines in operation and those that are not19. In the file dedicated to the Ardennes, a summary table tries to re-situate the setting of each production site precisely: in addition to the typical indications related to the location, an additional column notes nearby rivers, while another lists the techniques used. However, when the summaries are made or when departmental descriptions are published in the Journal des Mines, their authord take into account neither the very heterogeneous sources from which these figures emanate, nor the preparatory estimates that are made before completing the tables20.

Gradually, these summary documents were produced directly by mining engineers from data collected in the field, rather than by the clerical employees of the Conseil des Mines. Just as the factory inspectors at the end of the Ancien Régime managed simultaneously to draw up the minutes of their rounds and to develop "the state of manufactures"21, the ingénieur des mines of the Revolution and the Empire had to reconcile the descriptive ambition and the quantifying process in their approach to the territory, at least for the period when territorial knowledge was among the tasks assigned to them. Although it was not sustainable, this practice made mining engineers actors in the circulation of economic information and confirmed their role as intermediaries between the State and the operators. Directories, index cards and tables suggest that, like departmental statistics, topography made it possible to "move away from nomenclature towards the

\footnotetext{
18 Isabelle Charmantier, Staffan Mëller-Wille, « Natural History and Information Overlaod : The Case of Linnaeus ", Studies in History and Philosophy of Biological and Biomedical Sciences, vol. 43, n 1, 2012, p. 4-15. ${ }^{19}$ AN, F 14 4239, Dossier Dordogne, " Tableau des mines qui sont ou ne sont pas exploitées dans le district de Nontron ", s. d.

20 "Département de l'Allier », Journal des mines, vol. V, n²6, brumaire an V, p. 119-159.

21 Philippe Minard, La fortune du colbertisme. État et industrie dans la France des Lumières, Paris, Fayard, 1998.
} 
system and to introduce order and connections in their description"22. It serves as a matrix capable of structuring the data deemed essential for the management of the territory and its mineral resources.

\section{From paper records to spatialized data}

In various attempts to formalize data, for some space has served as an expedient to organize the data from surveys, if not a narrative thread. This was particularly evident in the singular use of maps that differed considerably from previous uses 23.

From the end of the seventeenth century, the Duke of Beauvillier's investigation, which to help the young Duke of Burgundy discover the French provinces' diversity, included certain reports that were accompanied by localization maps. A few decades later, several provincial-level survey plans insist on the need to include a map with the report in order to locate the space that is the subject of the description.

From the 1760s, the map was no longer just a location tool, it was more and more often compared to an illustrative image. For example, in an attempt to obtain an inventory of mineral resources in 1763, Bertin, who had just left the Contrôle général, decided to encourage and above all to finance the production of a mineralogical atlas of the kingdom he presented as a "general picture of the mineralogical productions of France" 24. He saw it as a "detailed atlas of the whole of France, in which the mineral quarries, the excavations, the mines, the mineral fountains, the materials of all kinds, which the earth contains within it, are represented by mineralogical signs" 25 . The analogy between a visual representation and the atlas was based on the desire to have a summary document which gathered the data deemed useful to depict the quantified or territorialized state of a place succinctly. All the mines, quarries, fountains, etc. had to be inventoried and localized.

Bertin entrusted this atlas project to two scholars, Guettard and Lavoisier. Born in 1715, Jean-Etienne Guettard was a member of the Academy of Sciences who completed a great number excursions and field observations; he also published a mineral map of France, in addition to maps of Paris, Etampes and Champagne. Antoine Laurent de Lavoisier was born in 1743, and it was his collaboration with Guettard, a friend of his father, which inspired his first works. Additionnally, Bertin offered the two scholars the know-how of the ingénieur-géographe, Dupain-Triel to whom he entrusted the cartographic production which

\footnotetext{
22 Marie-Noëlle Bourguet, Déchiffrer la France : la statistique départementale à l'époque napoléonienne, Paris, Éditions des archives contemporaines, 1989, p. 85.

${ }^{23}$ Jean-Marc Besse, Gilles A. Tiberghien (ed.), Opérations cartographiques, Arles, Actes Sud - École nationale supérieure du paysage, 2017.

${ }^{24}$ Antoine-Laurent Lavoisier, "Rapport sur les travaux du citoyen Dupain-Triel", CEuvres de Lavoisier, publiées par les soins de son excellence le Ministre de l'Instruction publique et des cultes, vol. IV, Paris, Imprimerie nationale, 1868, p. 644.

25 Idem.
} 
was to emanate from their investigation.26 Travelling through Normandy, Champagne, Ile de France, and Beauvaisis in 1764, the young Lavoisier wrote reports of his excursions entitled most often "Natural History Observations", in order to summarize his field notes. At Bertin's request in 1767, the two scholars undertook a trip together to the Vosges, where they were to glean as much information as possible in order to "complete the map". The result of these tours were sixteen maps that juxtapose a representation of the surface and stratigraphic cuts. This territorialized approach to mineral resources made it possible not only to overcome the perplexing challenges of accumulation and to make the inventory a tool for specifying the location of resources, but also to have essential data on the structure of the land before putting a site into operation.

At the end of the 1770s, while estimates of the territorial product appeared in large numbers,27 Monnet, who was still employed at the mine office as Inspector General, was entrusted by Bertin with the publication of the Atlas et description minéralogiques de France.28 To produce the printed version of the atlas, Monnet took the sixteen maps drawn up by Guettard and Lavoisier and produced twenty-nine others by appropriating the result of their observations. Monnet saw the mineral map of France as "a supplement of the great map of this kingdom".29 Not only did Cassini's map serve as a model but, more pragmatically, it was also used as the most suitable background for receiving mineralogical observations. The plates were reworked and simplified so as to avoid any graphic overload in order to focus on "the extent and position of the mineral substances".30

This concern echoes the Carte minéralogique de France, which came out of the Dupain-Triel workshop in 1781. This mineralogical map of France "where are marked the different principal terrains that divide this kingdom and the particular substances it contains," attempted to gather the data collected by Guettard on a single map. The ingénieur-géographe arranged the subdivision of France into three "main grounds"

\footnotetext{
${ }^{26}$ Palassou specifies in the introduction of his Essai sur la minéralogie des Monts-Pyrénées that he traveled the Pyrenees under the auspices of M. Bertin. His maps, however, are a statement and an ambition that seem different from those of Guettard. In fact, he juxtaposes in the volume he publishes a "Carte minéralogique des Monts-Pyrénées" that we can look at as a general map with a legend (called "Explanation of Mineralogical Signs"), eight detailed maps that each offer a more accurate representation of the valleys that appear on the larger map, and finally a large number of plates that offer cuts or views of the mountains described. Under no circumstances can this treaty be used as an index of mineral resources. Pierre-Bernard Palassou, Essai sur la minéralogie des Monts-Pyrénées, Paris, 1781, p. XII.

${ }^{27}$ Antoine-Laurent Lavoisier, De la richesse territoriale du royaume de France, texts and documents presented by Jean-Claude Perrot, Paris, CTHS, "Format", 1988, p. 63.

28 Jean-Etienne Guettard, Antoine-Grimoald Monnet, Atlas and Mineralogical Description of France, undertaken by order of the King, by MM. Guettard \& Monnet. Published by M. Monnet, according to his new travels. First part, including Beauvoisis, Picardie, Boulonnais, French Flanders, Soissonnais, German Lorraine, part of French Lorraine, the country Messin, and part of Champagne, Paris, at Didot, Desnos, Alexandre Young Jombert, 1780. The conditions for the elaboration and publication of this volume have been studied with great precision by R. Rappaport: Rappaport (Rhoda), "The Geological Atlas of Guards, Lavoisier and Monnet", in CJ Schneer, Toward a History of Geology, Boston, MIT Press, 1969, p. 272-287.

29 Jean-Etienne Guettard, Antoine-Grimoald Monnet, Atlas et description minéralogiques de la France, op. cit., p.V.

30 lbid., p. IV-V.
} 
but completed it with a very detailed explanatory table. Thus, more than the types of land, it was the "special resources" that took precedence here. The approach to territory is determined by points rather than surfaces. The map's cartouche confirms this reading since, in the manner of the plates of the Encyclopedia, it depicts the various stages of exploitation of mineral resources, from decision to extraction. In a brief summarizing the dispute between the Dupain-Triel and the Contrôle général, we find an outline of the work he did:

Sir Dupain Triel, geographer, proposed to make maps of the mines by generalities, taking as a model the large map of France which he would reduce the scale to a quarter, which would give still a concession of mines of 2400 radial measures an inch in diameter. These maps will provide by provinces, cities, towns, rivers, highways, outlines of forests and woods with places of establishments of glassworks, furnaces and other factories and central points of concessions. These maps will first be made by hand. We will wait to engrave them so that the information can undergo the necessary corrections. Three copies will be made of each of these maps: one to stay at the repository of commerce papers; another to be handed over to that of their lords the surveyors of commerce, in whose department is the generality, and the third to serve their lords the mine inspectors have the effect of marking what they have observed in their travels. 31

The map was to be explicitly intended for administrators concerned with the location of mineral resources; it would offer them a visual overview of the territory, but it would not be produced by them. If these maps were made, they have not been preserved. However, the project was resumed at the Maison des Mines, where from Year III, maps became the medium on which inspectors, engineers and sometimes even students recorded their observations.

Geographic maps would be used as tools for assembling diverse data gathered within the Maison des Mines. Moreover, in 1796, the Mining Council employed DupainTriel to create a map containing data previously gathered by its agents and contained in the files that we mentioned above. At first, each site was indicated on the map of each department, then these elements were transposed onto the map of inland navigation and routes, first published by Dupain-Triel in 1781 and revised in 1795. This new edition, entitled Tableau géographique de la avigation de l'intérieur du territoire républicain français, represented the entire navigable hydrographic network as well as the relief. The document was designed to present

at a glance all the mines and factories of the Republic and [...] to make known the means of circulation of the products, and the useful relations which the various establishments can have between them, the economy in the processes and the increase in activity that must result. It offers the means to facilitate public service supplies; finally, it presents useful views to commerce, whether internal or external 32.

\footnotetext{
${ }^{31}$ AN, F 141302 A, Document without title.

${ }^{32}$ AN, F 141301 B, « Compte-rendu par les membres du Conseil des mines, Paris le 22 frimaire an VIII »
} 
The emphasis was therefore very explicitly on the economic utility of this document. This initiative was part of the Mining Administration's broader mapping program which aimed to make the map a synoptic tool. In 1813, a circular issued by the Directeur general des mines announced a "mineralurgical map" project33. It would employ engineers to map out the "mineralurgical" establishments in detail and to provide a copy of this document to the Directeur general des mines. The goal of having cartographic information so detailed that it could indicate the limits resources was never achieved; however, we can clearly see that cartography offered the mining administration the means to synthesize and compare disparate data, in order to move beyond a simple catalog of observations by placing diverse information in a single spatial framework, creating the advantage of a sort of "absolute eye".

Maps were generally indispensable tools for the work of mining agents, not so much, like books, for the information they contain, but as frameworks used to receive their observations. Maps were an essential attribute mobilized by the mining agents during their missions. They always carried with them the pages of the Cassini map relative to their district, using them using them to record their field observations. A register of loaned Cassini maps has been preserved; the librarian recorded the name of each engineer and the numbers of the pages borrowed 34 .

In Year IV, when Pelletier was commissioned to inspect the second mineralogical region, the Mining Council had nineteen sheets of Cassini's map and two of the Belleyme map prepared for him. Then, on the 14th of Prairial, Year X (June 3, 1802), the ingénieur des mines Miché justified his request to Clouet for nine Cassini map pages, by explaining to the Mining Council that they would help him "better identify the places that will contain interesting objects in the departments he will visit" 35 . Precise location seems to be as a determining factor in the mining engineers' inventory work. Their use of maps testifies to the importance given to the territorialization of the information collected. From this point of view, their contribution to the incentive economic policy resulted from their work situating the mineral resources in an environment that made it possible to optimize their commercialization.

A tool that can capture data from surveys, maps were not only designed as tools for action, 36 but as a frame to arrange field data thanks to geographical coordinates. This

\footnotetext{
33 Isabelle Laboulais, « Aux origines de la carte géologique de France : retour sur les productions cartographiques du corps des Mines au cours du premier XIXe siècle », dans B. Belhoste, A.-F. Garçon (dir.), Les ingénieurs des Mines. Cultures, pouvoirs, pratiques, Colloque organisé par le CGIET pour le bicentenaire des lois de 1810, à Paris les 7 et 8 octobre 2010, Paris, Comité pour l'histoire économique et financière de la France, 2012, p. 19-31.

34 École des mines de Paris, ms. 78, V 3 et V 8.

35 École des mines de Paris, ms. 78, III 32.

${ }^{36}$ Dominique Margairaz, "La géographie des administrateurs", in Hélène Blais, Isabelle Laboulais (eds.), Géographies plurielles. Les sciences géographiques au moment de l'émergence des sciences humaines (1750-1850), Paris, L'Harmattan, Coll. "Histoire des sciences humaines", p. 185-215.
} 
approach would be implemented from the 1780s in the development of certain mineral collections.

\section{Spatialization of specimens}

In the eighteenth century, natural history collections were variously affected by the tendency towards systematic classifications; the field of mineralogy was no exception, though less so than botany which was governed by the system of Linnaeus.

Published in1784, Description méthdoique detailed the collection installed at the Hôtel de la Monnaie on the premises of the brand new École des Mines. The description's prefatory notice mentions the plan to create a complement to the systematic collection, a project that Sage attributed to Calonne, who as contrôleur general des finances was also the general director of the kingdom's mines.37 Sage planned to contribute some of his minerals to this new collection, and he expected that the surveyors would also be able to collect specimens. He conceived of this collection as the "mineralogical portrait" of the kingdom within which one could "gather the mineral productions of the kingdom and distribute them by order of department". The specimens were to be organized according to geographic order so as to offer a complete overview of the territory's resources. By housing and exposing France's "mineral riches", Sage hoped that this "national cabinet" would expand the usual audience of the École des mines beyond those who attended his public lessons. It would help increase knowledge for "the metallurgical economy"; the understanding of the different metals' properties would be improved; it would make it possible to discover techniques to melt and refine "at less cost and with more benefits". The installation was, however, delayed for lack of adequate space. In 1787 Sage addressed the project again, this time in the prefatory notice to his Supplément à la description méthodique du Cabinet de l'École royale des mines. 38 He reiterated his desire to "highlight the mineral production of France" and the need, in order to do this, for an additional 1600 square feet to deposit "the result of the national mines that will be ranked by order of department, so that these galleries will offer the mineral geography of France and will make known the real wealth of this kingdom", as if spatialization of data would suffice to reproduce the mineral geography of France. The project did not succeed under the Ancien Régime, but its principles were implemented at the Maison des Mines during the Revolution.

From Thermidor Year IV (July-August 1796), four distinctive collections were created and exhibited until 1814: a methodical collection classifying mineral substances by their properties; a geographical collection of all mineralogical productions around the globe and particularly those of the Republic, arranged by township and department; an economic

\footnotetext{
${ }^{37}$ Balthasar-Georges Sage, Description méthodique du cabinet de l'École royale des Mines, Paris, Imprimerie royale, 1784.

${ }^{38}$ Balthasar-Georges Sage, Supplément à la Description méthodique du Cabinet de l'École royale des mines, Paris, Imprimerie royale, 1787.
} 
collection which contained all the minerals useful in the arts and industry and focused on all transformations they undergo before being marketed; and finally, a collection of ore deposits to illustrate the variety of mines in heaps, layers, veins, etc. This geographical collection partly resumed the Calonne project that Sage defended from 1784 on. However, its "portrait" of the Republic's mineral resources was created in a different context. A first example of science at the service of action, a collection created in Year II shared the objectives of mining topography seen in the organization of the archives of the Maison des Mines and in the publication of departmental descriptions in the Journal des mines.

This collection gave rise to a singular exhibition plan, the Projet d'une distribution méthodique de la collection minéralogique de la France written in Year IV (1796) by the Ingénieur des Mines, Baillet.39 He proposed combining the principles of systematic distribution and topographical division, to benefit, as he put it, from the clarity of one and the simplicity of the other. If the instructions addressed to the Mining Corps in Year III to classify their samples by following the "order of the localities", Baillet did not intend to abandon the systematic classification methods because they are what turned the experimental sciences into "sciences of collection, analyses, classification and order." Nonetheless, Baillet's veiled terms suggested that topographical juxtaposition of minerals was a step backward. To avoid what he perceives as a simple accumulation devoid of intellectual ambition, Baillet proposed using two classifying methods: one based on the Republic's territorial departments and the other, on mineralogical classes.

To set up the first-floor section of the Maison des Mines devoted to collections, he imagined furnishing the side of a long gallery with cabinets measuring 2.5 meters high, a height which he believed would offer both the best conditions for viewing and the possibility of presenting a sufficient number of objects. For this, he recommended installing five shelves inside the cabinet in order to display from the bottom up the rocks, stones, soil and sands which compose the mass of a department's land; second, the earthy substances which are found in a pure, uncontaminated state in the mass of the land; next, the acidic substances with earth or alkaline base; then, the metals, metallic ores and the gangues which enclose them; the fossil fuels such as peat, bitumen, coal); and, finally large-sized lithological pieces. Although it was artificial, the order adopted here was an attempt to respect both the geographical distribution of minerals and the categories of scholarly classification. By placing at the bottom of the cabinet of the rocks, stones, soil and sands which make up the mass of a department's land, Baillet suggested a reproduction faithful to the original disposition; however, he made the effort to specify that the cabinets did not entirely reproduce reality, but only a partial reconstruction of the geological configuration. In this representation of nature, one must accept a loss of detail to gain intelligibility, for

39 Journal des mines, Pluviose Year X, Vol. XI, No. 65, p. 385-395 + 2 plates. 
this is the only way that the collection will be able to offer "a large picture of the French mineralogical landscape" 40.

Baillet designed a display that offered two approaches: a vertical reading made it possible to see at a glance the substances produced by the same department, while a horizontal reading offered an comparative presentation of substances of the same class. To provide an overview of mineralogical knowledge, the Inspecteur des Mines used classification and exposition techniques associated with other disciplines. He praised the ease with which a viewer could navigate in such a system, and he insisted even more on its potential to offer economic information. According to him, this layout made it possible to evaluate the wealth of France in this or that substance, as well as the mineralogical situation of each department. However, it preserved the categories used by mineralogists.

This analogy between the utilization of space in collections and the configuration of lands led Baillet to see the gaps in the cabinets (equivalent to the blanks of a mineralogical map) as a virtue: these empty spaces immediately indicated what substances were missing in the department represented. He himself established an explicit comparison between his classification system and cartographic productions: "Do we complain that geographers represent naked and uninhabited the scorching sands of Africa, the icy lands of the Arctic Circle, etc., etc.? We are grateful for the bareness of their maps, when they have the merit of truth and accuracy"41. We find here the legacy of Bourguignon d'Anville who eliminated the use of allegories from the maps to include only reliable data. For Baillet, this "collection will be the mineralogical tableau of France." This faithful representation would necessarily prevail: though a balanced distribution of objects in the windows might be more aesthetic, it would be devoid of all utility; above all, there would be a visual parallel between the table listing the collection's objects and the display layout of the collection itself.

Baillet saw this plan as "an easy way to tabulate the mineralogical catalog of France" and gave two illustrative plates as an example. The comprehensive catalog which he published proposes a reproduction of the collection, with objects being replaced by the words which serve to designate them. Baillet was aware that this "synoptic catalog" would be a "mere repertory", and that in no case it would serve as a treatise on mineralogy. Again, the difference with Sage is explicitly stated. The words that end Baillet's text show that while he saw that such a tool could be sufficient for the practician who inventories resources, it would not be satisfactory for the mineralogist, even if systematic classification did not totally disappear from the exhibition plan. This project of organizing one of the collections of the Mining Corps is perfectly in keeping with the objectives assigned to it during the Revolution and the Empire: it reconciled the achievements of mineralogy and the expectations of "mineralogical statistics"; it attempted to bring together the principles of inventory and the methods of classification. Even if the dimensions finally adopted in

\footnotetext{
40 Ibid., P. 387.

41 Ibid., p. 389.
} 
Year VII were slightly modified compared to Baillet's recommendations, this plan, which strove to give visible form to the land's underground structure, was applied in broad strokes to the cabinets installed on the first floor of the Maison des Mines.

A history of knowledge attentive to the instruments designed to order the information collected in the course of a survey highlights the place assigned to territorialization. Alongside the alphabetical order frequently used in the registers kept by administrations or the systematic order mobilized to arrange the scholarly collections, the geographical order prevailed at the end of the eighteenth century. It was not only a means to manage the increased amount of the data available in the reports and descriptions that reached Paris, but also a factor in the commensurability between scholarly and administrative knowledge. If the ambition to establish a rational administration of resources did not automatically result from this structuring of the data, it at least made it possible to organize information collected by one person and processed by another, to establish a link between these two groups and a link in the construction of the profession of ingénieur des mines.

The pragmatic approach to knowledge shows how much field knowledge required the establishment of an administration that had the logistic capacity to process, produce and disseminate information. These data processing methods required increases not only in the act of writing - copy work, summary essays, recording devices - but also in the amounts of storage space available to preserve all these files, ideally, near the offices where they were to be used. It is for this reason that in the summer of 1794, the Maison des Mines was created.

"Territorialisation and Logistics of Knowledge and Learning: The Case of Mineral Resource Surveys in France in the Eighteenth Century ", J. Vogel, L. Schilling (dir.), Transnational Cultures of Expertise. Circulating State-Related Knowledge in the 18th and 19th Centuries, Augsbourg, De Gruyter, « Colloquia Augustana », p. 149-165. 